Andzelika K. Gorzynska $\cdot$ Karin Denger

Alasdair M. Cook • Theo H. M. Smits

\title{
Inducible transcription of genes involved in taurine uptake and dissimilation by Silicibacter pomeroyi DSS-3 ${ }^{\mathbf{T}}$
}

\begin{abstract}
A largely untested hypothesis for the bacterial dissimilation of taurine was explored in Silicibacter pomeroyi DSS-3, whose genome has been sequenced. Substrate-specific transcription of candidate genes encoding taurine uptake and dissimilation $(\operatorname{tau} A B C, t p a$, ald, xsc, pta) was found, which corresponded to the induction of Tpa, Ald, Xsc and Pta, that was observed.
\end{abstract}

Keywords Reverse transcriptase PCR - Taurine dissimilatory pathway $\cdot$ Enzymes of taurine degradation

\section{Introduction}

Taurine (2-aminoethanesulfonate), the major organic solute in mammals (on average about $8 \mathrm{mM}$ in the human body), is synthesized in the liver and excreted largely in urine; mammals cannot cleave the c-sulfonate bond (Huxtable 1992; Stipanuk 2004). Corresponding to this ready supply of taurine, many terrestrial and marine bacteria utilize the compound, and two pathways of taurine dissimilation have been hypothesized around the key enzyme, the desulfonative sulfoacetaldehyde acetyltransferase [EC 2.3.3.15] (Xsc) (Fig. 1) (Cook and Denger 2006). Silicibacter pomeroyi DSS-3 ${ }^{\mathrm{T}}$, a marine bacterium, was found to grow with taurine as a sole source of carbon and energy, and quantitative utilization was established (González et al. 2003; Denger et al. 2006). A hypothetical degradative pathway was derived from the genome sequence (Fig. 1). It involved an ATP binding-cassette transporter (TauABC) [TC 3.A.1.17.1], a taurine:pyruvate aminotransferase (Tpa) [EC 2.6.1.77], Xsc and phosphate acetyltransferase (Pta) [EC 2.3.1.8] (Moran et al. 2004). The function of putative TauABC, orthologs of the Eschericha coli TauABC that was

A. K. Gorzynska · K. Denger · A. M. Cook · T. H. M. Smits ( $ه)$ Fachbereich Biologie der Universität Konstanz,

78457 Konstanz, Germany

E mail: Theo.Smits@uni konstanz.de

Tel.: + 497531884247

Fax: + 497531882966 characterized in sulfur assimilation (Eichhorn et al. 2000), has never been tested in a dissimilative pathway, and TauA shares only $23 \%$ identity with the characterized protein from E. coli. The putative Tpa shares 59 and $33 \%$ identity with the established orthologs in Bilophila wadsworthia RZATAU and Rhodococcus opacus ISO-5, respectively (Laue and Cook 2000a; Denger et al. 2004). The putative Xsc shares $75 \%$ identity with the characterized ortholog in Paracoccus denitrificans NKNIS (Brüggemann et al. 2004). Pta activity has been observed in some taurine degraders (Cook and Denger 2002; Cook and Denger 2006), but no pta-gene has been confirmed to be involved in the degradation of taurine. The need for an alanine dehydrogenase (Ald) [EC 1.4.1.4] in the hypothesis in Fig. 1 is known (Laue and Cook 2000b; Denger et al. 2004), as are roles for a sulfite dehydrogenase (sulfite oxidoreductase, Sor) and exporters of ammonium and sulfate ions, but candidate genes to encode the latter functions are either absent or unknown (Sor) or have not been confirmed (Cook and Denger 2006). Thus, despite the logic of the scheme in Fig. 1, and the utilization of taurine, there is no experimental support for a sometimes tenuous hypothesis (e.g., 23\% identity with a confirmed ortholog).

The aim was to test this genome sequence-derived hypothesis, using reverse transcription-PCR and enzyme assays to show that the postulated genes are indeed involved in taurine dissimilation. The structurally related compound cysteate (2-amino-3-sulfopropionate) is utilized as a sole carbon source by $S$. pomeroyi DSS-3 via cysteate sulfo-lyase (SPOA0158) (Denger et al. 2006) and not via Xsc, so we used cysteate-grown cells as one negative control to confirm the specificity of transcription of taurine-induced genes. The other control substrate for growth was acetate.

\section{Materials and methods}

Silicibacter pomeroyi DSS- $3^{\mathrm{T}}$ (González et al. 2003) was grown aerobically at $30^{\circ} \mathrm{C}$ in a modified Silicibacter 
Fig. 1 Hypothetical pathway for taurine degradation in $S$. pomeroyi DSS 3 (adapted from Cook and Denger 2006) (a) and the two small gene clusters encoding many of these reactions (b). TauABC (taurine $\mathrm{ABC}$ transporter), Tpa (taurine:pyruvate aminotransferase), Ald (alanine dehydrogenase), Xsc (sulfoacetaldehyde acetyltransferase), Pta (phosphate acetyltransferase), Sor (sulfite dehydrogenase), SPO3564 (putative sulfate exporter), Amt 1 (AmtB) (ammonia methylammonia transporter 1), Amt 2 (ammonia methylammonia transporter 2)

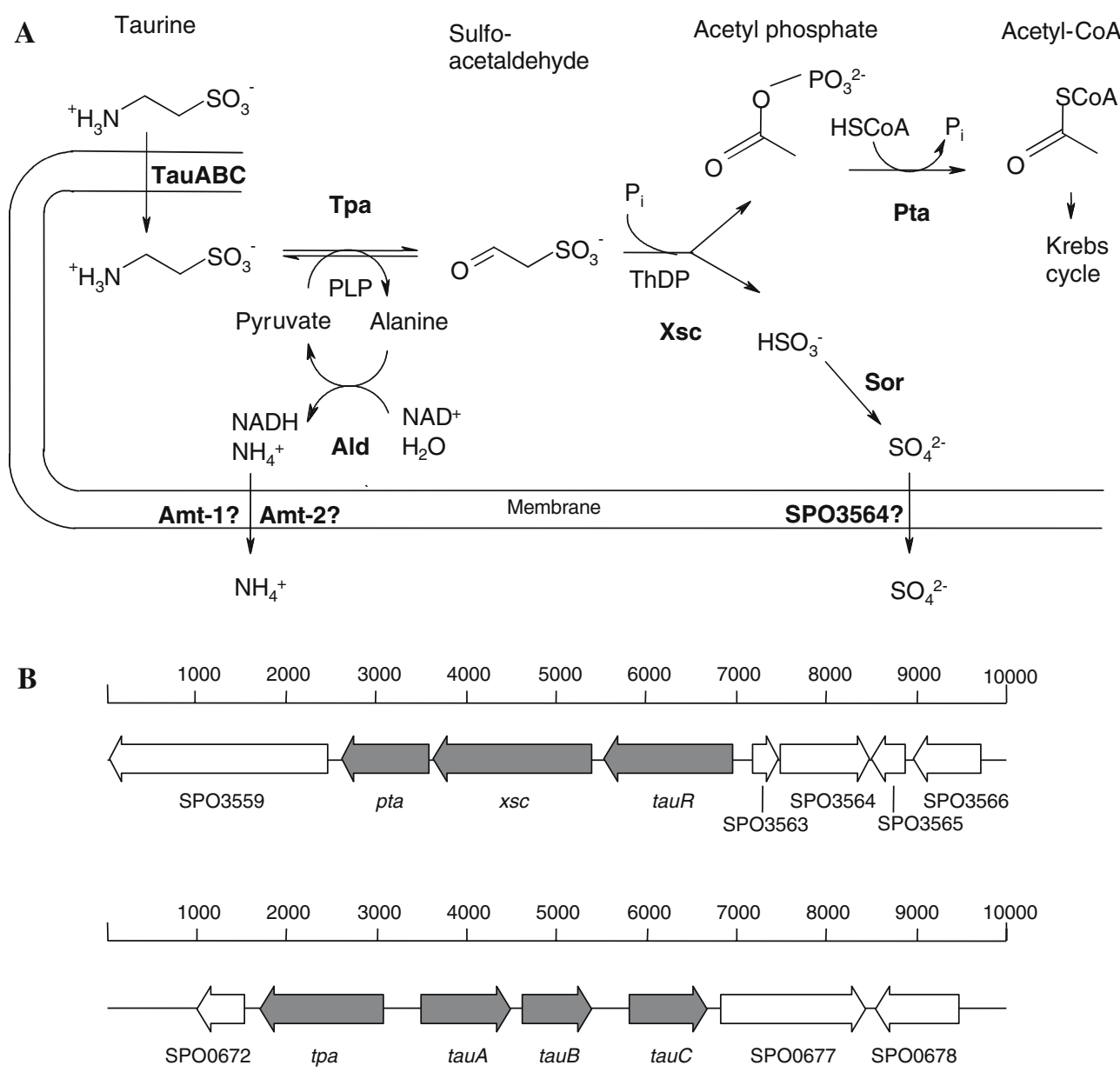

basal medium (SBM-M) (Denger et al. 2006). The sole added source of carbon and energy was taurine, cysteate or acetate, each at $10 \mathrm{mM}$. All growth experiments were done in 50-ml cultures in 300-ml Erlenmeyer flasks shaken at $30^{\circ} \mathrm{C}$. Samples were taken at intervals to measure optical density at $580 \mathrm{~nm}$. The growth rate $(\mu)$ with taurine was $0.12 \mathrm{~h}^{-1}$, with acetate $0.11 \mathrm{~h}^{-1}$ and with cysteate $0.07 \mathrm{~h}^{-1}$. Cells for the preparation of total RNA were grown in the required selective medium and harvested by centrifugation in the mid-exponential phase. Total RNA was isolated using the E.Z.N.A bacterial RNA kit (Peqlab Biotechnologie GmbH, Erlangen, Germany) and contaminant DNA was removed with RNase-free DNase (Qiagen, Hilden, Germany). The RNA was tested for presence of contaminant DNA before reverse transcription (RT) by PCR using the primer set SpXscF-SpXscR. The reverse PCR primers (Hermann GbR, Denzlingen, Germany) listed in Table 1 were used for RT with M-MuLV reverse transcriptase (Fermentas GmbH, St. Leon-Rot, Germany). Subsequent PCR reactions were done as described previously (Innis et al. 1990) and amplicons were detected on $1.5 \%$ agarose gels according to standard methods (Sambrook et al. 1989). Enzyme assays are cited where required (Table 2).

\section{Results and Discussion}

All five enzyme activities (Tpa, Ald, Xsc, Pta and Sor) hypothesized for the utilization of taurine were present in taurine-grown cells and effectively absent in acetategrown cells (Table 2). Three of these inducible enzymes (Tpa, Xsc and Pta) are also absent in cysteate-grown cells, while a fourth enzyme, sulfite dehydrogenase (Sor), can be anticipated in both sulfite-generating pathways (Table 2). Sor, detected recently (Denger et al. 2006), was confirmed to be independent of cytochrome $c$ and to be assayed with ferricyanide as an electron acceptor: no enzyme of this class has been characterized. Further, the data in Table 2 confirm the earlier observation (Denger et al. 2006), that Ald is induced to high levels in cysteategrown cells.

Transcripts for the candidate genes tpa, ald, $x s c$, and pta were detected in taurine-grown cells but not (or negligibly) in acetate-grown cells (Table 3). These transcripts are in agreement with the enzymic data, and, given the absence of known alternatives, consolidate support for the role of these genes in taurine metabolism.

The anticipated amplicon for the xsc gene (SPO3561) was obtained after reverse transcription with primer 
Table 1 Genes and primers used in this study

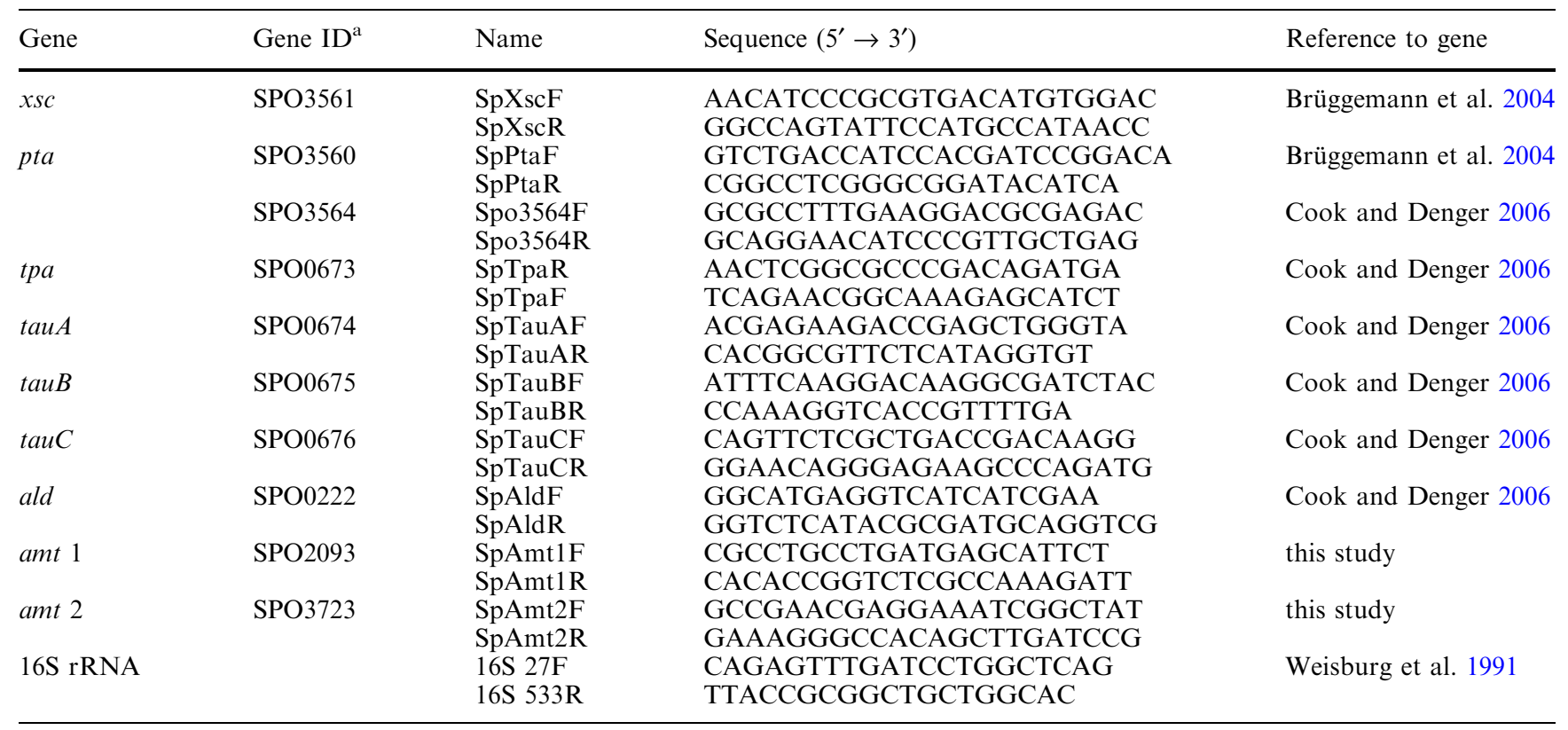

${ }^{\mathrm{a}}$ Gene ID according to annotated genome sequence (Moran et al. 2004)

Table 2 Enzyme activities (mkat/kg protein) in crude cell extracts from Silicibacter pomeroyi DSS 3 grown with different substrates

\begin{tabular}{lcccc}
\hline Enzyme & \multicolumn{2}{l}{ Growth of DSS 3 with } & & \multirow{2}{*}{ Assay in reference } \\
\cline { 2 - 4 } & Taurine & Cysteate & Acetate & \\
\hline Taurine:pyruvate aminotransferase (Tpa) & 16.7 & $\leq 0.2$ & $\leq 0.2$ & Laue et al. 1997 \\
L Alanine dehydrogenase (Ald) & 9.0 & 87.6 & $\leq 0.2$ & Laue and Cook 2000a \\
Taurine dehydrogenase (Tdh) & $\leq 0.03$ & $\leq 0.03$ & $\leq 0.03$ & Brüggemann et al. 2004 \\
Sulfoacetaldehyde acetyltransferase (Xsc) & 2.2 & $\leq 0.1$ & $\leq 0.1$ & Ruff et al. 2003 \\
Phosphate acetyltransferase (Pta) & 45.5 & $\leq 0.1$ & $\leq 0.1$ & Bergmeyer et al. 1983 \\
Sulfite dehydrogenase (Sor) & 3.2 & 3.8 & $\leq 0.03$ & Reichenbecher et al. 1999 \\
\hline
\end{tabular}

SpXscR (Table 3). After reverse transcription with primer SpPtaR (in SPO3562) and cDNA from taurinegrown cells, an amplicon spanning xsc-pta was obtained with primers $\mathrm{SpXscF}$ and SpPtaR, indicating that xsc and $p t a$ are located on a single transcript. Acetate-grown cells contained only traces of pta-transcript, and no induced activity was detected (Table 2).

Table 3 Results of the reverse transcription reactions

\begin{tabular}{llll}
\hline Gene & \multicolumn{3}{l}{$\begin{array}{l}\text { Amplicons found during growth } \\
\text { of S. pomeroyi DSS 3 with }\end{array}$} \\
\cline { 2 - 3 } & Taurine & Cysteate & \\
\hline tauA & + & Acetate \\
tauB & + & & \\
tauC & + & & \\
tpa & + & & Trace \\
ald & + & & Trace \\
xsc & + & + & + \\
pta & + & & \\
amt 1 & + & & \\
amt 2 & & & \\
spo3564 & & & \\
\hline
\end{tabular}

The ald gene was transcribed under all conditions tested (Table 3), but the transcript in acetate-grown cells was present in trace amounts, and enzyme activity was detected only in taurine- and cysteate-grown cells (see above). The ald gene is obviously regulated independently of the tpa, xsc and pta genes, which were not transcribed in cysteate-grown cells (Table 3 ).

Transcripts of the candidate genes $(\operatorname{tau} A B C)$ encoding a taurine transport system in $S$. pomeroyi DSS-3 were present during growth with taurine, but not during growth with cysteate or acetate (Table 3, Fig. 2). This is direct evidence that an ATP binding-cassette transporter is involved in the uptake of taurine during taurine dissimilation.

The gene of SPO3564, a potential permease with some sequence identity to presumptive sulfate exporters (Cook and Denger 2006), was not transcribed under the conditions tested (Table 3). The hypothesis of Cook and Denger (2006), that this might be the sulfate exporter, is apparently wrong.

Four genes for ammonia-methylammonia transporters (Amt) were identified on the chromosome (Moran et al. 2004). Based on a comparison with the known Amt 


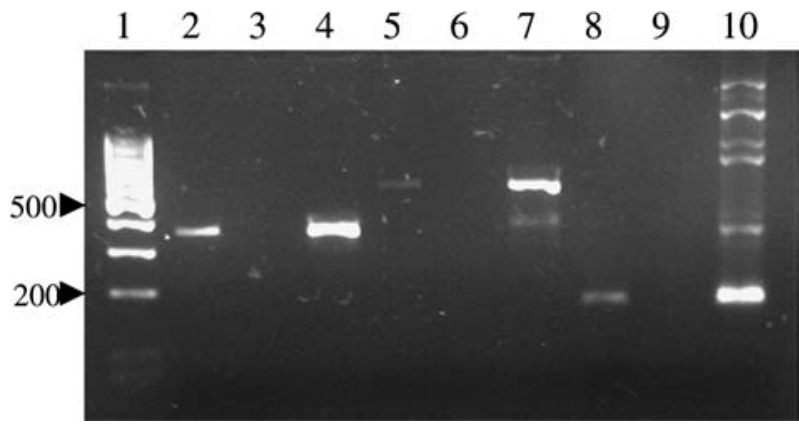

Fig. 2 Transcription of tauABC in taurine and acetate grown cells. Lane 1; Marker 100 bp: RT PCRs with primers; lanes 24 SpTauAF/SpTauAR, lanes $57 \mathrm{SpTauBF/SpTauBR,} \mathrm{lanes} 810$, SpTauCF/SpTauCR. Templates for reverse transcriptions: lanes 2/ $5 / 8$, RNA from taurine grown cells of $S$. pomeroyi DSS 3; lanes 3/ $6 / 9$, RNA from acetate grown cells of $S$. pomeroyi DSS 3. Lanes 4/ 7/10: positive controls using chromosomal DNA of $S$. pomeroyi DSS 3

proteins (Thomas et al. 2000), two of these were selected for RT analysis, amt-1 ((amtB) = spo2093) and amt-2 $(=$ spo3723). Whereas amt-1 was transcribed constitutively, amt-2 was transcribed in acetate-grown cells only (Table 2). This would suggest that Amt-1, which belongs to the ammonia transporting and sensory proteins [TC 2.A.49.1.1], could be involved in ammonium homeostasis, while Amt-2 belongs to the high affinity ammonium/methylammonium transporters [TC 2.A.49.2.3], and could be part of an uptake system for ammonia during growth with a substrate, which does not contain combined nitrogen. This suggestion needs to be tested experimentally.

Cook and Denger (2006) hypothesized a second pathway for taurine dissimilation, which involves taurine dehydrogenase [EC 1.4.2.-], that is presumably encoded by tauXY (Brüggemann et al. 2004; Weinitschke et al. 2006). No enzyme assay for taurine dehydrogenase showed activity (Table 2). This is in agreement with the absence of $\operatorname{tau} X Y$ genes in the genome of $S$. pomeroyi DSS-3.

\section{Conclusion}

Although several taurine dissimilatory enzymes have been assayed routinely (Laue and Cook 2000a; Ruff et al. 2003; Brüggemann et al. 2004), direct proof that a candidate gene was transcribed was often lacking. The present RT-PCR studies show clearly that the genes (tauABC, tpa, ald, xsc, pta) that were proposed to play a role in taurine degradation (Moran et al. 2004; Cook and Denger 2006) were induced during growth with taurine. The enzyme assays confirmed the activity of the gene products to be present in taurine-grown cells. We thus have evidence for the genes encoding the complete taurine catabolic pathway including uptake and dissimilation, and possibly for export of ammonia, whereas sulfite oxidation and excretion of excess anions in S. pomeroyi DSS-3 are still undefined.
The levels of sequence identity between the candidate genes in $S$. pomeroyi DSS-3 and orthologs with known function (Ruff et al. 2003; Brüggemann et al. 2004) were sufficient to assign their function in taurine dissimilation correctly. Our experience with newly available genome sequences (Ruff et al. 2003; Brüggemann et al. 2004; this study, T.H.M. Smits and A.M. Cook, unpublished results) shows that orthologs with high levels of identity to known genes for taurine dissimilation may fairly be presumed to encode enzymes or transporters of the predicted function. This fact is still largely ignored by the automated programs to annotate genome sequences.

Acknowledgments We thank Mary Ann Moran (University of Georgia, Athens, Georgia, USA) for discussions on the Silicibacter pomeroyi DSS 3 genome, The International Association for the Exchange of Students for Technical Experience (IAESTE) for supporting A.K. Gorzynska, and the University of Konstanz for financial support.

\section{References}

Bergmeyer HU, Graß1 M, Walter E M (1983) Phosphotransacet ylase. In: Bergmeyer HU (ed) Methods of enzymatic analysis, 3rd. edn. Verlag Chemie, Weinheim, pp 295296

Brüggemann C, Denger K, Cook AM, Ruff J (2004) Enzymes and genes of taurine and isethionate dissimilation in Paracoccus denitrificans. Microbiology (Reading) 150:805 816

Cook AM, Denger K (2002) Dissimilation of the $C_{2}$ sulfonates. Arch Microbiol 179:1 6

Cook AM, Denger K (2006) Metabolism of taurine in microor ganisms: a primer in molecular biodiversity? Adv Exp Med Biol 583:3 13

Denger K, Ruff J, Schleheck D, Cook AM (2004) Rhodococcus opacus expresses the xsc gene to utilize taurine as a carbon source or as a nitrogen source but not as a sulfur source. Microbiology (Reading) 150:1859 1867

Denger K, Smits THM, Cook AM (2006) L cysteate sulpho lyase, a widespread, pyridoxal $5^{\prime}$ phosphate coupled desulphonative enzyme purified from Silicibacter pomeroyi DSS $3^{\mathrm{T}}$. Biochem $\mathbf{J}$ 394:657 664

Eichhorn E, van der Ploeg JR, Leisinger T (2000) Deletion analysis of the Escherichia coli taurine and alkanesulfonate transport systems. J Bacteriol 182:2687 2795

González JM, Covert JS, Whitman WB, Henriksen JR, Mayer F, Scharf B, Schmitt R, Buchan A, Fuhrman JA, Kiene RP, Moran MA (2003) Silicibacter pomeroyi sp. nov. and Rose ovarius nubinhibens sp. nov., dimethylsulfoniopropionate demethylating bacteria from marine environments. Int J Syst Evol Microbiol 53:1261 1269

Huxtable RJ (1992) Physiological actions of taurine. Physiol Rev $72: 101 \quad 163$

Innis MA, Gelfand DH, Sninsky JJ, White TJ (1990) PCR proto cols. A guide to methods and applications. Academic, San Diego

Laue H, Cook AM (2000a) Biochemical and molecular character ization of taurine:pyruvate transaminase from the anaerobe Bilophila wadsworthia. Eur J Biochem 267:6841 6848

Laue H, Cook AM (2000b) Purification, properties and primary structure of alanine dehydrogenase involved in taurine meta bolism in the anaerobe Bilophila wadsworthia. Arch Microbiol 174:162 167

Laue H, Denger K, Cook AM (1997) Taurine reduction in anaer obic respiration of Bilophila wadsworthia RZATAU. Appl Environ Microbiol 63:2016 2021 
Moran MA, Buchan A, González JM, Heidelberg JF, Whitman WB, Kiene RP, Henriksen JR, King GM, Belas R, Fuqua C, Binkac L, Lewis M, Johri S, Weaver B, Pal G, Eisen JA, Rahe E, Sheldon WM, Ye W, Miller TR, Carlton J, Rasko DA, Paulsen IT, Ren Q, Daugherty SC, Deboy RT, Dodson RJ, Durkin AS, Madupu R, Nelson WC, Sullivan SA, Rosovitz MJ, Haft DH, Selengut J, Ward N (2004) Genome sequence of Silicibacter pomeroyi reveals adaptations to the marine envi ronment. Nature (London) 432:910 913

Reichenbecher W, Kelly DP, Murrell JC (1999) Desulfonation of propanesulfonic acid by Comamonas acidovorans strain P53: evidence for an alkanesulfonate sulfonatase and an atypical sulfite dehydrogenase. Arch Microbiol 172:387 392

Ruff J, Denger K, Cook AM (2003) Sulphoacetaldehyde acetyl transferase yields acetyl phosphate: purification from Alcalige nes defragrans and gene clusters in taurine degradation. Biochem J 369:275 285
Sambrook J, Fritsch EF, Maniatis T (1989) Molecular Cloning: A laboratory manual. 2nd Ed. Cold Spring Harbor Laboratory Press, New York

Stipanuk MH (2004) Sulfur amino acid metabolism: pathways for production and removal of homocysteine and cysteine. Annu Rev Nutr 24:539 577

Thomas GH, Mullins JGL, Merrick M (2000) Membrane topology of the Mep/Amt family of ammonium transporters. Mol Microbiol 37:331 344

Weinitschke S, Denger K, Smits THM, Hollemeyer K, Cook AM (2006) The sulfonated osmolyte $N$ methyltaurine is dissimilated by Alcaligenes faecalis and by Paracoccus versutus with release of methylamine. Microbiology (Reading) 152:1179 1186

Weisburg WG, Barns SM, Pelletier DA, Lane DJ (1991) 16S ribosomal DNA amplification for phylogenetic study. J Bacte riol 173:697 703 